\title{
DE INVLOED DER PRAKTIJK OP DE VORMING VAN HET NEDERLANDSCHE PROCESRECHT
}

\author{
DOOR \\ M.R. E. M. MEIJERS, \\ Hooglecraar to Leiden.
}

Sinds in 1811 de zoogenaamde summiere procedure in ons burgerlijk procesrecht is ingevoerd, hebben twee belangrijke herzieningen plaats gevonden; die van 1838, toen, voortbouwend op den Franschen code de procédure civile, ons Wetboek van Burgerlijke Regtsvordering werd ingevoerd en die van 1896, toen de zoogenaamde wet HARTOGH in werking is getreden. Beide heryieningen zijn door mannen van de praktijk met zorg voorbereid en door Staten-Generaal en Regeering van alle kanten bezien en besproken, bij beide stond vereenvoudiging van de procedure als hoofddoel op den voorgrond. Desniettemin werkt het raderwerk onzer rechtsbedeeling heden ten dage traag en gebrekkig.

Men trekt uit deze feiten de conclusie, dat onze wet in haar grondslagen verkeerd is, zoodat geen partiëele herziening iets blijvends uitrichten kan. Een andere eonclusie, die nog meer voor de hand ligt, is voor zoover ik weet nimmer daaruit getrokken. Het is deze: hoe allerellendigst moet de procedure geweest zijn, voordat men de twee groote herzieningen van 1838 en 1896 had tot stand gebracht. Deze conclusie heeft dit op de andere voor, dat haar juistheid an de hand van de ervaring kan getoetst worden. Ik heb mij deze moeite getroost. Tk heb indertijd. het archief der Amsterdamsche Rechtbank van de jaren 1811-1830 doorsnuffeld en heb bovendien de rechtspraak van nndere colleges vóór 1838, voor zoover deze gepubliceerd is, daarbij vergeleken. Welnu, mijn resultat is: in de eerste tien à twintig jaren na de invoering der Fransche procedure, was de gemiddelde duur van een summier of rol-proces in eersten aanleg: twee à drie maanden. Incidenten waren toen zeldzaam en werden door den rechter in zeer korten tijd afgedaan. Hij, die zich van de juistheid van mijn bevindingen zelf over- 
tuigen wil, neme maar eens de aardige verzameling ter hand van J. J. UiJTwerf Sterlina, Verzameling van vonnissen in zaken van koophandel van de Reytbank wan eersten aanleg te Amsterdam (1828). Hij vindt daarin een beeld van de wijze van procedeeren in het eerste tijdvak na de invoering van den Fransehen Code de procédure civile. Van de 35 procedures waarbij èn dag van dagvaarding èn dag van vonnis vermeld zijn, zijn afgedaan in een tijd

$$
\begin{aligned}
& \text { van 0-1 maand (j } \\
& \text { " 1-2 maanden } 8 \\
& \text { } 7-3 \text { त } 6 \\
& \text { "3-4 }, 3 \\
& \text { " } 4-5 \quad \text { n } 1 \\
& \text { } 5-6 \quad * \quad 4 \\
& \Rightarrow 6-7 ; 2 \\
& \text { "7-8 } \\
& \text { na een jaar } 2 \text { (beide met buiten- } \\
& \text { landers als partij). }
\end{aligned}
$$

Zie hier eenige staaltjes van de snelheid van procedeeren uit dien tijd:

Een procedure, warin 3 belangrijke vragen betreffende een noodlossing en avarijen te beslissen viel, was bij dagvaarding van $11 \mathrm{Febr}$. 1818 aanhangig gemaakt. Dng van het ronnis: 25 Maart $1818\left(\mathrm{n}^{\circ} .26\right)$.

Een procedure, waarin de vraag ter sprake kwam, of de houder van een cognossement aan order de voorkeur heuft boven den houder van een cognossement aan toonder, was bij dagvaarding van 29 Uetober 1818 aanhangig gemaakt. In deze procedure vond ten interventie plaats. Datg van het eindvonnis: 10 November 1818 ( $\mathrm{n}^{\circ} .47$ ).

Een procedure, waarin de commissiegever de door zijn commissionnair in prolongatie gegeven effecten opeischt, was aanhangig gemaakt 1 December 1819. 2 Februari 1819 viel het vonnis $\left(\mathrm{n}^{\circ}\right.$. 50; men leze daarbij vooral de merkwaardige turbe van Amstèrdamsche advocaten over den oorsprong der prolongatie).

De wederom actueele vraag welke de invloed op het contract van bevrachting was van het feit, dai, een schip aangehouden en belet wordt te vertrekken, omdat voor een anderen afzender verboden goederen waren ingeladen, kwam ter sprake in een procedure op 5 Mei 1819 aanhangig gemaakt. 14 Dagen later was het vonnis gewezen $\left(\mathrm{n}^{\circ}\right.$. 51).

De vraag of degene, aan wien een wissel onvolledig geëndosseerd is, bevoegd is den eigendom van den wissel over te dragen is beslist bij het vonnis van 30 Sept. 1819 in een zaak op 30 Augustus 1819 aanhangig gemaakt. In deze zaak, die het aanzien gegeven heeft aan 
art. 135,2 e lid W. v. K. is geappelleerd en ook bij den appelrechter werd in dien tijd in den regel vlugger dan thans geprocedeerd; 23 Februari 1820 viel het arrest van het Hooggerechtshof (n . 55).

De ansprakelijkheid van een schipper, die versehillende partijen onafgescheiden ingeladen had is vastgesteld bij het vonnis van 16 Dec. 1819 ; de degvaarding was 20 dagen vroeger uitgebracht $\left(\mathrm{n}^{\circ} .56\right)$.

Bij een dergelijke rechtspraak is ook te begrijpen, dat partijen in der minne een vragg aan den rechter onderwerpen om een twijfel tussehen hen op te heffen. Zoo b.v. is de vraag wat het geval is als onder geleverde effecten zich een uitgeloot nummer bevindt, twee dagen na de dagvaarding reeds door de rechtbank in haar vonnis beantwoord $\left(n^{\circ} .53\right)$. Ja $n^{\circ}$. 40 (vonnis van 5 Sept. 1818) geeft een onmiddellijke beslissing op denzelfde dag als de dag der dagvaarding.

De hier gememoreerde feiten moeten te denken geven. Fr moet dan toch nog een andere schuldige zijn dan de wet, die mede verantwoordelijk is, voor het feit dat onze procedure tot een instelling geworden is, waarvan men zeer zelden iets goeds hoort. Die schuldige is er; het is de praktijk. Dit aan te toonen zal het doel van dit artikel zijn.

\section{I.}

Het hoofdverschil tusschen een procedure van thans en een van voor honderd jaar, is dat de tegenwoordige procedure in tweeën geknipt is: een proces bestaat bijna altijd uit twee processen, eerst worden de rechtsvragen beantwoord en het schriftelijk bewijsmateriaal getoetst, daarna volgt als een tweede procedure: het getuigenbewijs.

Een zoodanige verdeeling van het proces in twee gedeelten was voor 100 jaar in de summiere of rolprocedure onbekend.

Op dezelfde zitting, warop de conclusies genomen werden, werd ter rolle bij incidenteele conclusie getnigenverhoor gevraagd. Gewoonlijk verzette zich de andere partij daar niet tegen en kon de rechter zonder veel tijdverlies zijn interlocutoor vonnis, dat getuigenbewijs oplegde, vellen. Na het getuigenverhoor had het eigenlijke pleidooi plaats en besliste de rechter bij zijn vonnis tegelijk de feitelijke vraag en de rechtsvraag.

Deze handelwijze was voor een groot deel een voortzetting van de traditie.

Ook ten tijde der republiek was het gebruikelijk, dat de rechtsvragen den rechter eerst ter beslissing werden voorgelegd na gehouden getuigenverhoor. Men kon weliswaar ook toen anders handelen. Meende 
één der partijën, dat het getnigenverhoor gcheel noodeloos de zaak zou rekken, omdat zijn wederpartij toch op een rechtsgrond verliezen moest, dan kon hij het getuigenverhoor vóórkomen en. werden partijen tot het pleidooi toegelaten.

Van dit middel werd echter zeer weinig gebruik gemaakt, omdat hij, die aldus wilde handelen, de zaak "te zijnen pericule" bepleiten moest. De gevaren aan dit "pleiten te zijnen pericule" verbonden, worden bij v. D. Linden "Verhandeling over de judicieele practijeq" geschetst; ik kan hier volstaan met naar dat werk te verwijzen. ${ }^{1}$ )

Deze praktijk nu werd voortgezet. Evenals v. D. LINDEN voor zijn tijd opmerkt, dat wanneer partijën omtrent de feiten verschillen, zij het omtrent het aan den rechter te vragen appointement meestal eens waren, zoo viadt men ook nog in den eersten druk van vaN DER HONERT's Formulierboek geen formulier van een conclusie van antwoord op een incidenteelen eisch tot het hooren van getuigen. In het formulier voor het vonnis, waarbij getuigenverhoor wordt opgelegd, komt slechts deze opmerking voor: "Deze rordering van den eischer is door of namens den gedaagde niet wedersproken". ${ }^{2}$ )

Het Iaten vóórgaan van het getuigenverhoor vóór de bepleiting der rechtspunten had ook een wettelijke basis. Art. 15 van titel $V$ van het decreet van 16/24 Augustus 1790, hetwelk den eisch van motieveering der vonnissen invoerde, noemde immers de rechtsvraag $n a$ de feitelijke vraag. Het is hetzelfde, wat thans art. 59, $30 \mathrm{Rv}$. voorschrijft.

Eén geval kende men nochtans vóór 1838 , waarin ook reeds toen de gebruikelijke manier van procedeeren was: eerst de rechtmatigheid der vordering volgens het gestelde onderzoeken en daarna het getuigenbewijs toelaten. Het was de echtscheidingsprocedure. Dit steunde echter op de artt. 246 en 247 van den Code civil, die in iedere echtscheidingsprocedure een vonnis verlangden, waarbij de vordering tot echtscheiding werd toegelaten of niet-ontvankelijk verklaard. Hier waar, alvorens tot het vonnis van toewijzing te kunnen komen, een tusschenvonnis dat den eisch toeliet, noodzakelijk was, gold als reden ran niet-

1) v. D. LINDEN, t. a. p. II, 8.

2) v. D. Honent, t. a. p. formulier 44.

Nog zij opgemerkt, dat bij die reshterlijke colleges, die zelfs na 1811 genoegen namen met buitengerechtelijke, voor een notaris afgelegde, verklaringen van getuigen, deze steeds fegelijk met het overige bewijsmateriaal an 's rechters oordeel werden onderworpen. Zie omtrent deze Amsterdansche praktijk Briefoisseling van eenige regtsgelecrden over de aunstande Nederlandsche votgeving, 1819, bl. $228 \mathrm{vlg}$. 
ontvankelijkheid ook dat echtscheiding op een niet door de wet erkende grond gevraagd werd ${ }^{1}$ ).

In 1827 heeft men aan deze bijzondere regeling voor echtscheidingsprocedures een einde willen maken. Art. 48 van den zesden titel van het derde boek van het nieuw voorgestelde wetboek luidde: „De zaak zal behandeld worden in denzelfden vorm, welke voor andere vorderingen is vastgesteld."

Ongewijzigd is deze bepaling in 1838 wet geworden (zie art. 822). Tegenwoordig let niemand meer op deze bepaling. En inderdaad, zij kan thans gerust gemist worden. Echter, om deze merkwaardige reden: wat vóór 1838 een bịzondere wijze van procedeeren alleen voor echtscheidingen was, is thans door de practijk de algemeen gebruikelijke geworden,

Mear in de jaren $1820-1830$ was dit nog in geenen deele het geval. Art. 822 , 1e lid Rv. was toen van ingrijpende beteekenis. Men leze slechts hoe de bekende Amsterdamsche advocaat LipMax in 1827 het artikel bekritiseert:

"Voortreffelijk is het stelsel door den Franschen Wetgever aangenomen, waarbij deze procedure in twee gedingen wordt gesplitst, en warbij, met omkeering der gewone orde, in de cerste plaats het regtspunt wordt beslist, in de tweede de daadzaken worden uitgemaakt. Klaarblijkelijk is des Wetgevers bedceling, dat het bij vonnisse moet zijn uitgewezen, dat het stelsel des eischers in regten gegrond is, alvorens hij tot het feitelijk bewijs van dat stelsel wordt toegelaten...

Wij meenen daarentegen in het Ontwerp geheel te moeten afkeuren de gelijkstelling van dit geding met andere gewone vorderingen, de toepassing daarop van alle gowone regtsvormen, met alle die vereenvoudiging, welke het Ontwerp kenschetst."

„Er bestant niet meer. die tweevoudige procedure, waarin eerst het onderzoek plaats had, of de eiseh, zoodanig als die was ingesteld, met het regt strookte, en of de feiten (derzelver waarheid voorloopig aangenomen), de vernietiging des huwelijks konden wettigen. Wij hobben steeds in de dwaling verkeerd, dat het van den Franschen wetgever eene wijze vinding was, den eisch, zoo die op rechtsgronden niet konde worden toegelaten, zonder verder onderzoek, onmiddellijk af te wijzzen. Wij waren altijd van begrip, dat het, in zoodanig geval, verkieslijker was, de waarheid of onwaarheid der feiten in twijfel te

1) Zie de Malevili.e op art. 246 . 
laten, dan door een nutteloos getuigenverhoor de echtgenooten nog. meerder tegen elkander te verbitteren. Die laugrame, en, zoo wij meenden, regelmatige gang is afgeschaft, en. door een spoedigen en eenvoudigen loop vervangen. De ontwerpers hebben hier de bijzondere verdienste, dat zij de goede ingezetenen in staat hebben gesteld, eene echtscheiding schier zoo gemakkelijk te verkrijgen, als de ontruiming van eenen wanbetalenden liuurder, en, met een enkel vonnis, in omtrent twee maanden, met de uribgave van: minder dan vijftig guldens, eeuen lastigen echtgenoot kwït te jaken 1 )."

Getuigt dit eene citaat niet meer dan de meest uitvoerige betoogen, hoe op den duur het niet de wet, maar de praktijk is die het procesrecht maakt? Want welke practicus van heden zal niet glimlachen, wanneer hị leest, dat een echtscheiding op tegenspraak zoo gemakkelijk te verkrịgen is, dat zij, met de enquête inbegrepen, in omtrent twee maanden kan plaats vinden en nog geen vijftig gulden zal kosten. Marr het is dien practicus ook geheel onbekend, wat art. 822, 1e lid Rv. eigenlijk bedoeld heeft.

\section{II.}

Hoe is het nu gekomen, dat de praktijk een geheel andere geworden is? Dat eerst afzonderlijk over de rechtsvragen gedebatteèrd wordt en daarna pas het getuigenbewijs aan de orde komt?

Drie omstandigheden hebben dit in de hand gewerkt:

$1^{\circ}$. De wettolijke eiseh dat de door de getuigen te bewijzen feiten ter zake dienende en afdoende" moeten zijn.

$2^{\circ}$. Het middel van niet-ontvankelijkheid.

$3^{\circ}$. De subordinate conclusie tot het leveren van getuigenbewijs.

\section{III.}

Ad $1^{\circ}$. - het ter zake dienende en afdoende van het getuigenbewijs.

Dit vereisehte voor de toelaatbanrheid van getuigenbewijs is van zeer ouden oorsprong. Zoo ver wị in de geschiedenis van het romeinschcanoniek proces der middeleeuwen kunnen terug gaan, is de eisch gesteld, dat een foit, dat men aanbood door getuigen te bewijzen, moest

1) S. P. LipMAN, Aammerkingen op het ontwoerp van wetboeh van burgerlijke regtspleging, 3e stukje 1828, bl. 92,93 en bl. 128. 
zijn : concludent en pertinent. Of gelijk men het ook uitdrukte: frustra probatur quod probatum non relevat 1 ).

Men heeft dezen regel echter vroeger niet zoo streng opgevat, dat eerst de gegrondheid van den eisch in thesi moest uitgeprocedeerd zijn, alvorens men tot bewijs door getuigen van de gestelde feiten kon toegelaten worden. De rechter vond in het vereischte van het ter zake dienende en afdoeade ees geschilt middel om een getuigenverhoor, waarvan de noodeloosheid hem duidelijk zonder veel onderzoek bleek, niet te houden. Reeds Durantis en zijn leermeester Bernardos verklaren, dat de rechters dikwijls partijen ter bekorting der procedure zonder veel onderzoek tot het getuigenbewijs toelieten, de vraag van het ter zake dienende daarbij tot do cindbeslissing aauhoudende ${ }^{2}$ ).

Ook nog in het begin der 19 do eeuw geschiedde bij den Nederlandschen rechter het onderzoek of de te bewijzen aangeboden feiten ter zake dienende en afdoende waren, zeer summier.

Het vaste model van een interlocutoor vonuis, waarbij getuigenbewijs opgelegd werd, - ook nog te vinden in den eersten druk van. $\mathbf{r}$. D. HoxerT's Formulierboek - levert daarvan het duidelijkst bewijs.

Nudat geconstateerd was, dat bepaalde feiten gesteld en ontkend waren en dat bewijs door getuigen was aangeboden, werd alleen nog overwogen: , overwegende, dat deze daadzaken behooren tot de zoodanige, waarvan het bewijs bij getuigen door de wet is toegelaten, en dit bewijs tot beslissing kan leiden" (of.: „en ter .zake dienende en afdoende zijns").

Men vergelijize dararmede eens de tegenwoordige interlocutore vonuissen, vol ingewikkelde rechtsbeschouwingen!

$\mathrm{Nog}$ in een arrest van den Hoogen Raad van 22 Juni $1860 \mathrm{~W} .2181$ in eerste instantie gewezen, vind ik èn door den Hoogen Raad èn door den procureur-generaal de vraag of de staatsrechtelijke verplichting van den staat om een haven te onderhouden grondslag kan rijn voor een vordering nit onrechtmatige daad ter zijde gelaten, waar beslist moest worden of de door den eischer ten bewijze aangeboden feiten ter zake dienende en afdoende waren. De procureur-generaal merkt in deze conclusie terecht op, dat slechts dan feiten als niet ter zake dienende en afdoende mogen beschouwd worden, wanneer de

1) Gewoonlijk wordt als oorsprong genoemd C. 4.19.21. Veelecr is de oorsprong echler in het canonieke recht te vinden: X. 1. 29.36 en de glosse sub verbo, nihilominus. De formule, frustra probatur etc. is van Durnorss.

2) Duranris lib. I c. $4 \$ 5$. n. 4; causa litis abreviandae judices eos admittunt salvo iure impertinentium sicut et positiones ut notat dominus meus in prae c. per tuas. 
vordering "kennelijk" ongegrond is en "a priori gezegd zou moeten worden, dat de feiten niet ter zake dienende en afdoende zijn."

Ferst onder invloed van de hierna onder $2^{\circ}$ en 3 te bespreken invloeden is men "het ter zake dienende en afdoende" gaan opvatten als met zich brengend de noodzakelijkheid alle rechtsvragen ten gronde te beslissen, voordat tot getuigenbewijs kan overgegaan worden.

Echter in één opzicht leefle de oude opvatting nog stecds voort. Werden door een rechter feiten ter zake dienende en afdoende geoordoeld, dan werd deze beslissing door den Hoogen Raad als een feitelijke aangemerkt ${ }^{1}$ ).

Vooral het arrest van 18 April $1873 W .3583$ is in deze merkwaardig. Het niet ter zake dienende en afdoende van het getuigenbewijs was beweerd, omdat de eischer nimmer aan de door hem gestelde feiten zijn beweerd vorderingsrecht kon ontlconen. De Hooge Raad overwoog dienaangaande:

O. daaromtrent, dat dit middel is gerigt tegen het bevolene getuigenverhoor op grond, dat nu reeds zoude blijken de niet-ontrankelijkheid der ingestelde vordering; dat zulks, al ware dit zoo, dan nog dit niet zoude meebrengen het ongeoorloofde van het bevolen getuigenverhoor, vermits het angehaalde a $99 \mathrm{~B}$. R. tot de toelating daarvan alleen vordert, dat partijen het over de daadzaken niet eens zijn en het bewijs door getuigen bij de wet is toegelaten, en het mede aangrehaalde a. 203 van hetzelfde wetb. het getuigenbewijs veroorlooft, indien de ontkende daadzaken zijn ter zake dienende en afdoende, waarvan de beslissing geheel aan den feitelijlen regter is overgelaten".

Een beslissing thans geheel vergeten, maar die men diende wederom nieuw leven te geven.

Dat overigens in dien tijd het getrigenbewijs reeds een andere plaats was gaan innemen, kín uit de twee navolgende omstandigheden blijken. In de eerste plaats beeft de Hooge Raad tusschen de jaren 1844 en 1852 eenige malen verklaard, dat de beslissing, dat te bewijzen aangeboden feiten ter zake dicnende en afdoende waren, wel in cassatie kon aangevallen worden ${ }^{2}$ ). De nietw wich vormende practijk was der-

1) Zie H. R. 8 Januari $1846 W 6$ 690, 9 Mei $1856 ; N . R$. dl. $53 \$ 9,14$ Mei $1858 W .1960,9$ December $1859 \mathrm{~W} .2131,18$ April $1873 \mathrm{~W}$. 3583, 23 Oet. 1873 W. 3652,20 Januari 1898 W. 7074.

2) H. R. 31 October 1844 v. D. H., B. R. 6, 129,22 October 1847 v. o. H., B. R. 9. 115,9 Mart 1849 v. D. H., B. R. 10. 300,25 Mei 1849 v. D. H., O. Z. 9, 81, 16 Mei 1851 v. D. H. 13.81 ; 5 Mant 1852 v. d. H, 14. 189. Zie ook de Pento II $\$ 154$. 
halve sterker dan de oude, aan een vorig geslacht ontleende leer. In de tweede plaats verdiepte de Hooge Raad zich reeds in de zeventiger jaren, ten gronde in alle rechtsvragen oin het ter zake dienende en afdoende van een getuigenverhoor vast to stellen, wanneer hij een zaak in eerste instantie behandelde. Typisch voorbeeld daarvan is b.v. het arrest van 9 Juni 1871 W. 3340.

\section{Daarin wordt overwogen:}

$O$. wat betreft het al of niet toelaatbare der incidentele vordering, dat de beslissing der vraag, of de zes laatste, niet erkende, daadzaken zijn ter zake dienende en afdoende, staat in een onafseheidelijk verband tot de vordering ter principale, in zooverre namelijk de toelating tot bet bewijs danrvan veronderstelt de toewj̄gbar.heid der vordering, welke toewijsbaarheid reeds nu door den gedaagde is bestreden; en dat bijgevolg ter beoordeeling van het al of niet toelantbare der incidenteele vordering reeds $\mathrm{nu}$, doch alleen in zooverre, behoort te worden onderzocht het al of niet toewijsbare der principale vordering $\mathbf{1}$ ).

Zoo heeft dus dit vereischte van het "ter zake dienende en afdoende" medegewerkt om in een afzonderlijke procedure de rechtskwesties te doen vóórgaan. Na de zeventiger jaren is echter deze invloed nauwelijks meer merkbaar. Het middel van niet-ontvankelijkheid vervulde sindsdien uitsluitend de rol waarin het vroeger nu en dan door den eisch van het pertinente en concludente gesteund was. Ook verdwenen in de practijk de zelfstandige incidenteele conclusies tot toelating tot bewijs door getúigen.

\section{IV.}

Ad $2^{\circ}$. Het middel van niet-ontvankelijkheid.

Het middel pan niet-ontyankelijkheid is steeds iets geweest, waarvan de practici den mond vol hadden, zonder dat zij zelve goed wisten, wat dit eigenlijk was. De lotgevallen van het middel van niet-ontvankelijkheid in den loop der tijden zijn te merkwaardig dan dat ik ze hier terloops vermelden kan; ze zijn een afzonderlijk artikel waard.

Ten allen tijde is men het echter hierover eens geweest dat het middel van niet-ontvankelijkheid een exceptie was, staande tegenover een verdediging ten principale. Wat men echter onder een exceptie verstaan moest en welke excepties middelen van niet-ontvankelijkheid opleverden, daaromtrent bestond de onzekerheid.

1) In de conclusie van den advocaat-generaal Karśroom wordt natnurlijk geargnmenteerd met den regel: Frustra probatur quod probitum non relevat.

Merkwaardig is ook E. R. 23 Nov. 1854 v. D. H. 20. 72. (met conclusie!) 
Iı onze Nederlandsche praktijk der eerste helft der 19de eèuw had men een ruime opvatting omtrent het middel van niet-ontvankelijkheid. Anders dan de Fransche juristen, liet men vrijw wel iedere exceptie tot een niet-ontvankelijkheid leiden ${ }^{1}$ ). En de rubriek der excepties was zeer omvangrijk doordat als zoodanig ook beschouwd werden de verweringen: tibi non competit hace actio (met de nadruk op tibi) ${ }^{2}$ ) en tibi non competit haec aetio contra me (met den nadruk op contra mo $)^{3}$ ).

Nochtans sprak men in den annvang der 19 de eeuw niet van een exceptie of een middel van niet-ontvankelijkheid, wanneer het gestelde geheel geen recht opleverde. Art. 3271 van het ontwerp 1820 noemde het dan ook een verweer ten principale, leidende tot een ontzegging van eisch, „wanneer door den gedaagde aangevoerd werd, dat schoon de feiten en omstandigheden mogten wanrachtig zijn, nogtans daaruit geene wettige rechtsvordering voortspruit". Zoo was ook aanvankelijk de praktijk. Ja nog in cen conclusie van den procureur-generaal in een zaak, die in 1871 voor den Hoogen Raad in eersten ganleg behandeld werd, is_deze opvatting weer te vinden. De procureur-generaal merkt op : delen:

„Ik stel mij voor de volgende drie vragen zeer beknopt te behan-

Voureerst is de regtsvordering ontvankelijk?

Ten anderen: is xij behoorlijk in facto gestaafd?

Ten derden: is zij rechtens gegrond P" 4).

Onder dit laatste punt wordt dan de rrang besproken of nit onrechtmatige daden van ambtenaren een civiele vordering tegen den Staat ontstaat.

Echter een dergelijke beperkte opvatting der niet-ontvankelijkheid was reeds in 1871 ouderwetsch.

Mr. de Pinto, die in zijn Handleiding, exceptie en middel van nict-ontvankelijkheid geheel gelijk: stelde, nam onder de exceptiën ook

1) Faure: I, 328, oe PiNTo, Handleiding II, 291, Faber, De leer der exceptiën en niet onluankelijlaheid bl. 30 .

2) Voorbeelden uit de rechtspraak van den Hoogen Raad: 16 Juni 1843, (v, D. H. B. R. 3, 170.) 25 October 1844 (id. 6, 74) 7 Juni $1850(12,84), 17$ Januari 1851 (12, 275), 14 Februari $1851(12,344) 22$ October $1852(15,208)$ enz.

3) H. R. 28 Juni $1844(5,372)$, 31 Oetober $1851(13,221)$, 22 Oetober $1852(15,208)$ 30 Juni $1853(17,121)$. Zie ook de niteenzetting wat een middel van niet-ontvan. kelijkheid is in de conelusie bij H. R. 5 Nov. 1840 (v. v. H. I. 288).

t) Conclusie bij H. R. 13 Januari 1871, W. 3284. 
het verweer op: non competit actio ${ }^{1}$ ). En FABER in zijn in 1850 verschenen brochure, De leer der exceptiën en niet-ontvankelijkheid, gaf dit kenmerk van het middel van niet-ontrankelijkheid: „Bij niet-outvankelijkverklaring laat de gedaagde zich over de door den eischer gestelde daadzaken niet uit" (blz. 32). De practijk van na 1850 is vrij algemeen van gelijke opvatting.

F.aure heeft zich tegen deze stroom truchten te verzetten ${ }^{2}$ ). Ook hij identificeerde middel van niet-ontvankelijkheid met exceptie, maar daar volgens hem de bewering, dat de gestelde feiten het ingeroepen gevolg niet rechtvaardigen, een verdediging ter principale is, wenscht hij ook bij deze bewering niet van een njet-ontvankelijkverklaring, maar van een ontzegging van eisch weten. Slechts een enkele maal is men Faure op dit punt in de praktijk gevolgd. Zoo b.v. in het arrest van den Hoogen Raad van 20 Dec. 1895, W. 6750, waarin het heet: ${ }_{n}$ of de door den eischer in de dagvaarding vermelde middelen zijn van dien aard, dat de conclusie der dagvaarding daaruit noodzakelijk volgt, is eene vrang .rakende de al of niet toewijsbawheid der vordering ${ }^{3}$ ).

Geheel anders is datentegen de meening van den procureur-general van den Hoogen Raad in 1908. Evenals FABER, evenals de gangbare practijk, verklnarde deze: „outvankelïk is de actie, zoodra ze „in thesi" voor toewijying vatbaar is" 4). En ook de Hooge Raad achtte bij arrest van 15 April 1910 W. 9018 terecht beslist, dat een in een dagvaarding gestelde feitelijke grondslag, onvoldoende is om den eisch in zijne vordering te doen ontvangen". Evenzoo wordt in het arrest van 29 April 1910 W. 9027 een niet-ontvankelijkverklaring uitgesproken omdat als grond van den eisch in de dagvaarding gesteld was de inbreuk op een publiekrechtelijk beheersrecht en daaruit geen civielrechtelijke vordering kon voortvloeien. Het is, kan men zonder gevaar van tegenspraak opmerken, bij den Hoogen Raad vast gebruik geworden om een niet-ontvankelijkheid uit te spreken in alle gevallen, waarin uit het gestelde het ingeroepen gevolg niet voortvloeit ${ }^{5}$ ). Zoo ook bij alle overige rechtscolleges.

Men is dientengerolge thans tot de noodzakelijkheid gekomen om gronden van niet-ontvankelijkheid te erkennen, die ambthalve door den

1) de Pinto II, 251.

2) Fa ure I, 309-319.

$\left.{ }^{3}\right)$ Zie ook nog de procureur-generaal Pol.ss en zijn conclusies bij H. R. 6 December 1901, $W$. 7692, en 19 Februari $1909, W .8826$.

4) Conclusie bij het arrest van 16 April $1908, W .8700$.

s) Zie 0. a. H. R. 24 Maart 1916, W. 9972 , en 1 Mei 1914, W. 9668. 
rechter moeten aangevuld worden t), terwijl men vroeger een middel van niet-ontvankelijkheid als een rechtsmiddel beschouwde, dat door partijen moest anngevoerd worden ${ }^{2}$ ) en dat dientengevolge ook niet voor het eerst in cassatie kon opgeworpen worden ${ }^{3}$ ).

Welke invloed heeft nu de verruiming van de rubriek der nietontvankelijkheden op den loop der procedure gehad?

Een middel van niet-ontvankelijkheid moet gelijk zijn naam aanduidt, door den rechter vóór andere weren onderzocht worden; zijn juistheid ontheft den rechter van ieder verder onderzoek naar de gegrondheid der vordering.

Deze roorrang bij het onderzoek van den rechter is nochtans van weinig belang, wanneer de middelen van niet-ontwankelijkheid tegelijk met het verweer ten principale moeten voorgedragen worden en het getuigenbewijs aan het vonnis voorafgaat. Immers de invloed van het feit dat een verwering een middel van niet-ontvankelijkheid is, beperkt zich dan tot de volgorde warin de verweermiddelen in het eindvonnis besproken worden.

Het voordragen der verweermiddelen was nu èn in het oud-Hollandsche recht èn in art. 160 van het Wetboek 1838 zoo geregeld, dat - behalve eenige met name genoemde - alle peremptore exceptiën tegelijk met het verweer ter principale rnoesten voorgesteld worden. En onder de heerschappij van den Code civil mochten slechts de dilatore excepties aan de défenses au fond voorafgatan (art. 186).

Het getuigenverhoor ging aanvankelijk na 1811 evenals in het oudHollandsche recht, nog aan het onderzoek der verweermiddelen in de hoofdzaak vooraf. Of derhalve eenig verweermiddel moest leiden tot

1) Zie b.v, het arrest van 1 Mei 19.44 , W. 9668, met mijn onderschrift.

2) Zelfs een algemeene conelusie tot niet-ontvankelülverklaring was niet voldoende; H. R. 5 Nov. 1840 (v. v. H. 1, 292), 18 Maart 1841 (v. D. H. 2, 192), 26 Nov. $1852, \not F, 1387,30$ Juri 1853, W. 1450,21 April 1859 (v. D. H. 23, 224) en 4 Februari 1887, $\because$. 5398. Anders H. R. 16 Juni 1843 (v. D. H. 4,500) en 26 Juni $1863(27,470)$.

3) Nag dilswijls klinken in de rechtspraak van den Hoogen Raad stemmen uit het verleden $Z_{00}$ b.v. H. R, 16 Mart 1906, $W$. 8353: "een middel van niet-ont.vankelijkheid kan niet voor het eerst in cassatie worden atngevoerd en onderzocht." De procureur-generaal Röser bij H. R. 16 Mei 1884,W. 5035: "hoe dit ook zị̆, zoo betreft de grief een middel van niet-ontvankelijkheid; het gevolg daarvan zou zijn, dat de oppositie tegen het dwangbevel a limine litis zou zijn afgesneden en zoodanig rechtsmiddel kon niet voor liet eerst in cassatie worden aangewend."

Zie ook H. R. 14 Maart 1873, $W .3569$, en de in vorige noot genoemde arresten. 
een ontzegging van eisch of tot een niet-ontvankelijkheid, was dan ook in dien eersten tijd van weinig praktisebe beteekenis.

Dit veranderde echter geheel, toen in zwang kwam getuigenbewijs aan te bieden bij subordinate conclusie, toegevoegd aan cen primair verweer in de hoofdzaak.

V.

Ad $3^{\circ}$., de subordinate conclusic tot het leveren van getuigenbewijs.

Het is tegenwoordig in de praktijk algemeen gebruikelijk om getuigenbewijs in zijn conclusies in de hoofdzaak aan te bieden en wel, alleen voor het geval, dat de overige aangevoerde juridische en feitelijke argumenten onvoldoende zijn om de zaak zonder nader bewijs te winnen.

Zoo algemeen is dat gebruik, dat bij een practicus nimmer de gedachte opkomt of dit wel in overeenstemming met de wet is en of de praktijk wel altijd zoo geweest is. Ja, de meeste juristen weten niet eens meer - iets, wat men toch in ieder handboek van procesrecht lezen kan dat voor de wet een verzoek om tot getuigenbewijs toegelaten te worden, nog steeds niets anders dan een incidenteele conclusie is. Het bewijs, dat zij het niet weten, is, dat zij er niet aan denken, om wanneer hun wederpartij in een conclusie van dupliek getuigenbewijs angeboden heeft, voor zich het recht op te eischen om daarop met een nadere conclusie te antwoorden. En toch heeft men dit recht, want roorzoover er getuigenbewijs aangeboden wordt, is de conclusie een incidenteele conclusie van eisch, waarop men bevoegd is in een incidenteele conclusie van antwoord bescheid te geven. En in deze incidenteele conclusie van antwoord kan dan weer het ter zake dienende en afdoende van het aangeboden getuigenbewijs bestreden worden, d.w.z. volgens de heerschende opvatting, kin nader ingegaan worden op het geheele verweer van den gedaagde. Het is ditmaal wellicht gelukkig, dat de meeste advocaten beter de praktijk dan de wet kennen.

Het aanbieden van getuigenbewijs, niet bij zelfstandige incidenteele conclusie, maar: in de conclusies van de hoofdzaak en dan alleen "voor zooveel noodig", of gelijk het rroeger heette bij subordinate conclusie, is eerst na 1838 in de praktijk in zwang gekomen. Deze praktijk voorzoover ze het getuigenbewijg aanbiedt, subordinaat aan zuiver juridische verweermiddelen, is in strijd met de wet. Partijen kunnen geen verandering brengen in de volgorde waarin de rechter volgens de wet de geschilpartijen moet onderzoeken. De wet nu schrijft eerst onderzoek van de daadzaken, daarna van de rechtsvragen voor. Slechts door 
in het juridisch verweer een exceptief middel van niet-ontvankelijkheid te zien, wiens toetsing aan het onderzoek ten principale moest voorafgann, kon men de praktijk eenigszins rechtvaardigen. 'Terzelfden tijd als de opkomst van de subordinate conclusie vindt dan ook de verruiming van het middel van niet-ontyankelijkheid plaats. Deze twee tezamen hebben de splitsing der procedure in twee gescheiden bedrijgen veroorzaalkt.

Nog in het jaar 1851 was de praktijk der subordinate conclusie van getuiger'bewijs niet zoo doorgedróngen of men dorst haar wettigheid voor den Hoogen Rand betwisten. En het betrof toen nog slechts een conclusie, subordinaat aan de 'bewering, dat de feiten reeds door de geproduceerde geschriften 'bewrezen 'waren. De verweerder in cassatie beriep zich onder meer er op, "dat zoodanige wijze van procedecren door de algemeen aangenomen jurisprudentie was gewettigd."

De procureur-gencraal vaN MAANEN, representant van een tijd, toen de subordinate conclusie onbekend was, verzette zich in zija conclusie tegren de incidenteele vordering:

${ }_{n}$ Het gaat niet aan, dat de regter eerst zal moeten onderzoeken, of de eischer zijne vordering in regten genoegzaam heeft gestaafd; en zoo neen, of $a$ de aard der zaak dan een getuigonbewijs toclaat en of $b$ de gestelde feiten concludent zijn en dat de regter lan zal interloqueren om naderhand nogmaals de zaak au fond te onderzoeken en te beslissen. Zoodoende toch doet de regter werkelijk twee. malen ten principale uitapraak, eerst over het primaire, als voldoende geoordeelde, later over het subordinatelijk geleverde "bewijs."

De Hooge Raad zelf dacht er anders over. Hij oordeelde, dat de gevolgde wijze van procedeeren wellicht minder regelmatig mocht wezen, maar nergens door de wet verboden was. Uit het feit, dat de rechter ambtshalve een getuigenverhoor kon gelasten, bleek ook, dat een getuigenverhoor, zelfs na het houden der pleidooien over het geding ten principale, door de wet niet met den aard der zaak wordt strijdig geneht, indien zulks tot ontdekking der waarheid kan leiden ${ }^{1}$ ).

De Hooge Raad bedacht hier niet, dat het ambtshalve gelaste aanvullend getuigenbewijs, na gehouden pleidooien in de zaak ten priucipale, evenals in strafzaken, uitzondering moest blijven, doch dat dit tengevolge van zijn arrest onherroepelijk en blijvend de algemeene regel zou worden.

Reeds in 1860 wist de praktijk niets anders dan, dat men getuigen-

') H. R. 4 April 1851, v. D. H., Burg. Zaken deel XIV, blz. 338. 
bewijs aanbiedt bij subordinate conclusie, ingelascht in de conclusies in de hoofdzaak. De Rechtbank te 's-Gravenhage moest op 13 April $1860, W .2182$ een vonnis vellen, om te verklaren, dat men ook getuigenbewijs bij zelfstandige incidenteele conclusie kon ranbieden!

\section{VI.}

De gewijzigde aard van het interlocutoor heeft zich in den loop van den tijd hoe langer hoe seherper geteekend

Van het moment, dat reeds in het interlocutoor de voornaamste rechtsvragen der procedure werden beantwoord, werd het ook gewenseht, dat men tegen dit interlocutoor in cassatie kon opkomen. Oorspronkelijk ging dit niet; de beslissing, dat daadzaken ter zake dienende en afdoende warer, werd, gelijk opgemerkt is, door den Hoogen Raad als een feitelijke beschouwd, waartegen in cassatie niet kon opgekomen worden.

Anders werd dit echter toen men dezelfde vraag ging stellen en beantwoorden in den vorm of de eischer in zijn vordering niet-ontvankelijk verklaard moet worden. Een ontvankelijkverklaring is immers. door den Hoogen Raad steeds als een eindbeslissing aangemerkt, waartegen cassatiemiddelen gericht kunnen worden ${ }^{1}$ ). 'l'egenwoordig worden dan ook bijna evenvele cassatieberoepen tegen interlocutore vonnissen als tegen eindronnissen ingesteld. Door de moderne opvatting der ontvankelijkverklaring won dit rechtsinstituut aldus an practische beteekenis.

\section{VII.}

Ook de regel, l'interlocutoire ne lie pas le juge, moest met het interlocutoor vonnis van beteekenis veranderen. Zoolang in een interlocutoor vonnis geen beschouwingen voorkwamen omtrent de vraag of de vordering in rechte gegrond was, of zoolang deze vraag slechts summierlijk in een navant faire droit" besproken was om het ter zake dienende en afdoende van gestelde feiten te beslissen, zoolang ook was het een regel, die van zelf sprak, dat het feit, dat de rechter getuigenbewijs opgelegd had, voor haar geen beletsel behoefde te zijn, om dit getuigenbewijs geheel ter zijde te laten en op een geheel anderen grond, een

1) Men vergelijke hierbij het ondersehrift bij $\mathrm{H} . \mathrm{R} .24$ Maart 1916, W. P. N. en $R .2432$ en de aldaar besproken arresten van dew Hoogen Raad. Zij geven een duidelijk beeld van het veranderde karakter van het interlocutoor vonnis. 
rechtsgrond, den eisch te ontzeggen of toe te wijzen $\left.{ }^{1}\right)$. Thans echter, au bij het interlocutoor vonnis, de rechtskwesties na ampele voorbereiding en toelichting van partijen beslist worden, wordt het een dwaasheid, wanneer de in het ongelijk gestelde de bevoegdheid zou hebben daarop voor den zelfden rechter onder aanhaling van den regel: linterlocntoire ne lie pas le juge terng te komen. De regel zelf heeft men niet op zij durven zetten. Zijn toepasselijkheid is echter aanzienlijk beperkt, wederom, door in de beslissing, dat de gestelde feiten het geëischte rechtvaardigen, een ontvankelijkverklaring te zien en een ontvankelijkverklaring in deze als een eindbeslissing aan te merken ${ }^{2}$ ).

\section{VIII.}

De invloed der wijziging der praktijk uitte zich. eveneens bij de inrichting van het vonnis.

Gelijk reeds opgemerkt is; wensoht de wetgever, dat in het vonnis eerst de feitelijke en daaraa de rechtsuragen zullen beslist worden. Dit blijkt nog eenigszins uit de artt. $59,3^{\circ}$ en $424 \mathrm{Rv}$. Tegen woordig meent men dat men aan art. $59,3^{\circ}$ voldaan heeft door een relaas te geven van al hotgeen in judicio geschied is. De gronden der uitspraak, wat de daadzaken betreft, behooren echter te bevatten - gelijk aanvankelijk algemeen gebruik was - datgene wat in het proces vast staat en datgene wat niet bewezen is; de overwegingen, dienaangaande thans onder de overwegingen in rechte ondergebracht, hebben met ${ }_{n}$ het regtspunt" niets uit te staan. Nog duidelijker dan in art. 59, $3^{\circ} \mathrm{Rv}$. stond de eisch, dat eerst de feiten moeten vastgesteld worden, voordat de rechter tot zijn rechtsbeschouwingen mag overgaan, in het wetboek 1830 ;

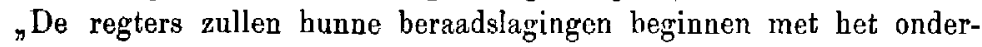
zoek van de daadzaak, en daarna van het recht" (art. 39).

1) Dat de rechtsbeschouwingen, warop lict ter zake dienende en. afdoende van een getuigenbowijs is aangemomen of verworpen, den rechter niet binden, is op grond der oude traditie nog beslist door H. K. 24 Dec. 1914, W 9775 en 31 Dec. $1909 \mathrm{H} .8958$ (beide echter ten aanzien van oen door den verweerder aangeboden bewijs). Waren dezelfide beschouwingen echter aangemerkt als een uitspraak omtrent de ontvankelijkheid, dan was de rechter wel gebouden geweest. Zie de volgende noten.

2) Wen zie in het bïzonder H R $23 \mathrm{Juni} 1916 \mathrm{~W}$. 10005. Na dit arrest kan men zeggen, dat de regel l'interlocutoire ne lie pas le juge, in zijn vroegere beteekenis dood is, Men vergelijke ook H. R. 24 Januari $19137 \% .9473$ en 26 Juni $1903 W .7987$ (naust het interlocutuor Rotterdan 24 out. 1900 W. 7586). 
Waarom is deze bepaling weggelaten? De verslagen der afdeelingen en der centrale afdeeling der Tweede Kamer geven het antwoord. De eerste afdeeling vond de bepaling, „un peu trivial, le droit naît du fait et il est difficile de s'occuper du premier sans être d'accord sur le second on du moins sans l'avoir décidé" 1). Nog sterker luidt het in het verslag der centrale afdeeling: men vond de bepaling onvoegzaam daar zij een te groote onkunde in den regter veronderstelt, terwijl hịj ook vrij blijft dezelve niet na te komen 2). Bleef vór 1830 de Regeering het nut der bepaling volhouden, bij de herziening in 1837 heeft zij het voorschrift "als nutteloos," weggelaten 3).

Er zit humor in de geschiedenis. In 1828 en 1837 vond men het onvoegzaam bij den rechter zooveel onkunde te veronderstellen, dat hij cerst de rechtsvragen en dan de feitelijke vragen zou beslissen, eenige tientallen jaren later bljjkt door geheel Nederland die onkunde aanwezig te zijn, want trouw worden, onder de mom der ontpankelijkheidsvraag, eerst de rechtsvragen en daarna pas de feitelijke vragen beslist.

Tevergeefs beeft FAURE ettelijke malen getracht den Nederlandschen rechter tot ander inzieht te brengen ${ }^{4}$ ) en hem op art. 59, $3^{\circ} \mathrm{Rv}$. gewezen. De rechter kon aan art. $59,3^{\circ} \mathrm{Rv}$. niet meer zijn natuurlijken zin geven, sinds hij van het middel van niet ontrankelijkheid een vóórprocedure omtrent de rechtsvragen gemaakt had.

Wanneer men de vonnissen van één bepaald college van af 1811 nagaat, dan komt men steeds tot het tijdstip, waarop de vorm der vonnissen zich gewijzigd heeft.

Voor de arresten van den Hoogen Raad in eersten aanleg gewezen is dat het jaar 1853 geweest. Tot dien datum werd zonder uitzondering bij de overwegingen, wat de daadzaken betreft, nagegaan, welke feiten in de procedure reeds bewezen waren. $\mathrm{Na}$ dien bepalde men zich er toe onder deze overwegingen alleen op te nemen de verschillende door

1) Noornzier, W. v. B. R. IT, bl. 395.

2) Noorbzieк, $W$. o. B. R., II bl. 619 .

ง) v. D. HonLRT, bl. 199.

Ook Lismas solureef in zijn bespreking van art. 39 van het ontwerp 1827: Door deze wetsbepaling worlen in de stellige wetgeving twee regtsbeginselen opgenomen, welker gegrondheid nimmer in twijfel getrokken is. Het eerste is, dat men het regtspunt niet kan beslissen, alvorens de daudzaak to hebben uitgemaakt, nam (om de woorden van Molinaeus te bezigen) modica circumstantia facti jus variat. Zie ook het citaat, bierboven bl. 163 gegeven.

4) Z00 0. a. in Rechisgel. Magazion IX, bl. $570 \mathrm{vlg}$. 
partijen gedane beweringen; wat bewezen was, vond een plaats onder de overwegingen in rechte 1 ).

$B \mathrm{jj}$ vele der overige colleges is de verandering reeds vele jaren eerder geschied. Merkwatardig is in dit opzicht het arrest van den Hoogen Raad van 8 Januari $1846(W .690)$, waarbij bevestigd werd het arrest van het Hof van Friesland van 8 Januari $1845(W .607)$. Het Hof van Friesland had zijn arrest ingericht op de moderne wijze; onder de overwegingen ten ånzien der daadzäken waren alleen dé judicieele feiten opgesomd; of de door den eischer aangevoerde feiten bewezen waren, was onder de overwegingen, in rechte nagegaan. Hiertegen werd nu in cassatie aangevoerd, dat daarmede art. $59,3^{\circ}$. Rv. geschonden was, omdat niet afzonderlijk over daadzaken en regtspunten beslist was.

Dit middel is overeenkomstig de conelusie van den advoeaat-generaal verworpen. In deze conclusie vordt opgemerkt, dat art. 59, $3^{\circ}$. Rv. kennelijk alleen ten doel heeft om te voorkomen, dat „de uitspraak in facto niët mot de beslissing in jure wordt verward, maar geene bepaalde orde vaststelt, waarin die onderscheidene beslissingen in een vonnis of arrest moeten worden terneergesteld".

En de Hooge Raad overwoog: "dat hoezeer de redactie van het - arrest in verschil ontwijfelbaar met meer juiste uit-elkander-houding cn nauwkeuriger splitsing quod ad factum en quod ad jus had kunnen zijn ingesteld, echter die onderscheiding daarbij in het wezen der zaak niet zoodanig is veronachtzaamd, dat daardoor zon zijn geschonden het voorschrift van voornoemd wetsartikel."

Wat de Hooge Raad hier als de ontwijfelbaar meer juiste splitsing beschouwde, was hij eenige jaren later geheel vergeten. $\nabla$ an het jaar 1855 immers richtte de Hooge Raad bij zijn rechtspraak in eersten

1) Men vergelijke voor ile inrichting der arresten in eersten aanleg vór 1853 :

H. R. 21 Januari 1842 (v. D. H., B. R. 3. 165) 28 Juni 1844 (ibid. 5,368 ) 16 Maart 1849 (10, 336) 30 Nov. 1849 (11, 100), 13 Dec. 1849 (11, 111) 22 Februari $1850(11,275) 25$ October $1850(12,112) 29$ November $185 n(12,190), 14$ lebruari 1851 (12, 344) 2 Junuari $1852(14,8)$, 21 Mci 1852 (14, 386), 11 Juni $1852(15,40$ en 15,61$) 8$ April $1853(16,261)$;

voor de andere wijze van inrichting van hot vomis:

7 Januari $1853(16,138) 18$ Maart 1853 (16, 202) 15 April 1853 (16, 316) 9 Juni $1854(18,430) 26$ Januari $1855(19,34) 11$ Juni $1858 \quad(22,352) 11$ Maart 1859 (23, 161) 31 Mei 1861 (25, 308) 9 Mei $1862(26,410) 29$ Oct. 1863 $(28,52) 11$ Januari $1867(31,44) 8$ Maart $1867(31,139)$ enz.

Een enkele maal treft men nog eens de juiste opvatting aan: 26 Juni 1863 $(27,489)$ : wat door getuigenverklaringen bewezen is, wordt onder de daadzaken vermeld, evenals in het arrest van 21 Mei $1852(14,386)$ geschied was. 
aanleg zijn arresten op geheel gelijke wijze als het Hof van Friesland in; de overwegingen ten aanzien der feiten werden slechts een nutteloos en door de wet nooit bedoelde herhaling van de beweriugen van partijen.

\section{IX.}

De praktijk zette ten slotte de kroon op het gansche werk, toen zij invoerde de conclusies na enquête en het dubbele pleidooi.

Zoolang het getuigenverhoor een incident in de procedure was, hetwelk bij incidenteele conclusie werd gevraagd, concentreerde zich de mondelinge behandeling der zaak in het pleidooi nò de gehouden enquête; te zamen werden alsdan de feitelijke en de rechtskwesties bepleit.

De latere afzonderlijke behandeling van de rechtskwesties on van het getuigenbewijs heeft er toe geleid, dat men beide deelen van het proces gelijkwaardig ging beschouwen en van dezelfde attributen ging voorzien. Zoo hebben zich de conclusies na enquête, niettegenstaande de wet deze niet kent, ingeburgerd. Z 00 ook is geheel in strijd met de bedoeling der oorspronkelijke wet een dubbel pleidooi, één vóór het interlocutoor vonnis en één vóór het eindvonnis in zwang gekomen.

X.

De invloed der praktijk heeft zich nict tot de geschetste splitsing van het proces bepaald. Nog op tal van andere punten kan hij aangetoond worden. En nimmer heeft de praktijk in de rolprocedure een vereenvoudiging gebracht. Voor een deel hangt dit samen met het feit, dat de summiere of rolprocedure na 1838 in de praktijk meer en meer de algemeene procedure werd, zoodat de wetgever van 1896 ten slotte de in onbruik geraakte gewone procedure zonder bezwaar kon opheffen. Maar toch rechtvaardigt deze verruiming van het gebied der rolprocedure niet de verslapping, die de praktijk daarmede gepaard liet gan. Ook toch in den tijd toen het nog een snelwerkende procedure was, werden niet enkele onbeteekenende, maar vele en zeer belangrijke zaken krachtens haar berecht. Ik wijs slechts op haar toepassing in zaken van koophandel.

De voornaamste der veranderingen, door de praktijk bij de rolprocedure in het leven geroepen, lat ik hier volgen.

Om te beginnen dan het aantal der conclusies.

Onder de heerschappij van den Code de procédure civile was het dubieus of in de summiere procedure wel conclusies mochten gewisseld worden. De praktijk liet echter een conclusie van eisch en een van 
antwoord toe. Het wetboek van 1838 heeft deze praktijk van twee conclusies gesanctionneerd (artt. 138 en 139 oud.). Na 1850 zijn echter bij de rolprocedure ook een conclusie van een re- en een van dupliek in zwang gekomen, aanvankelijk onder protest. Nog bij het arrest van den Hoogen Raad van 22 Februari 1878, W. 4219, besliste de Hooge Raad, dat de rechter op deze conclusies, als in de wet onbekend, geen acht mocht slaan.

Zes jaar later capituleerde ook de Hooge Raad voor de praktijk. Hij overwoog: dat wel in de artt. 138 en 139 Rechtsvord., de procedure regelende in summiere zaken, enkel wordt gesproken van twee conclusiën, eene van eisch en eene van verwering, en wordt bepaald, dat nn het nemen dier conclusiën partijen worden toegelaten tot de pleidooien of daartoe een nadere dag wordt bepaald, doch dat hierin niet ligt opgesloten een verbod om nog nadere conclusiën te wisselen, en zulks dan ook in de practijk gebruikelijk is." (Arrest van 10 April 1884, W. 5027) ${ }^{1}$ ).

Toen in 1896 de vicr conclusiën in de wet werden vastgelegd, werd niets anders gedaan dan dat de wet de praktijk sanctionneerde. Een vooruitgang was het eehter geenszins.

Bij toeval liet men in de wet echter nog staan, dat onze gewone procedure een mondelinge is! (Art. $162 \mathrm{Rr}$.). Gelukkig! want als het niet in de wet stond, zou niemand op de gedachte komen on onze tegenwoordige procedure bij voorkeur eene bij mondelinge voordracht te noemen. Het pleidooi is een episode uit de procedure, meer niet. En - behalve in cassatie - niet eens de gewichtigste. Dikwijls blijft het dan ook geheel achterwege.

\section{XI.}

Hoe in strijd met den oorspronkelijken opzet de latere praktijk stceds meer en meer, in de rolprocedure de paperassen een rol heeft doen spelen, blijkt ook bij bet getuigenverhoor.

De conclusies na enquête hebben we reeds vermeld. Maar daarnaast is ook de wijze, waarop de getuigenverklaringen ter kennis van den rechter komen, geheel gewijzigd.

De enquête in de rolprocedure was aanvankelijk bedoeld en werd

1) $\mathrm{Zie}$ ook arreston van 6 Docember $1889, W .5808$, en 22 Januari 1897, W. 6922. Het langst hebben zich verzet: Rb. Winschoten 7 April 1886, $W .5363$, en Rb. Niddelburg 10 November $1886, W$. 5468. 
ook aldus opgevat, om onmiddellijk daarna of met een zeer korte tusschenruimte gevolgd te worden door het pleidooi. Vandaar dat bij deze proeedure het getuigenverhoor voor het college zelf en niet voor een rechter-commissaris moest geschieden (art. 200), vandaar ook, dat een proces-verbaal van het verhoor alleon behoefde opgemaalkt te worden, indien de zaak appellabel was (art. 241. C. de Pr. civ. en art. 200 nevens art. 110 W. v. B. R. 1838); het proces-verbaal was voor den appèlrechter bestemd.

Echter toen het gebruik werd, dat er geruimen tijd tussehen de enquête en het eindvonnis verliep, dat er conclusies en pleidooien tusschenbeiden kwamen, zoodat de rechters, die bij het getuigenverhoor aanwezig waren, bijna steeds anderen waren dan die het vonnis velden of zoo zij dezelfde waren bij het vellen van het vonnis het geheele verhoor reeds vergeten waren, toen werd het eenerzijds dwaasheid om het getuigenverhoor voor het college en niet voor een rechter-commissaris te doen houden, anderzijds moest toen wel het proces-verbaal van het getuigenverhoor het stuk worden, waarop feitelijk beslist werd.

Wat het eerste betreft, zoo burgerde zich reeds vóór 1896 bij groote rechtbanken het gebruik in om het getuigenverhoor ook bij de rolprocedure voor een rochter-commissaris te doen houden.

Bij 3 arresten heeft de Hooge Raad het onwettige van deze handelwijze uitgesproken ${ }^{1}$; het bleef nochtans bij de Rechtbank te Rotterdam gewoonte. Bij de herziening van het wetboek in 1896 werd dartegen nog eens gereageerd; uitdrukkelijk werd in de wet bepaald, dat het getuigenverhoor vóór alle rechters moest gehouden worden. De voorsteller wees op de wenschelijkheid, dat de rechters, die de zaak hebben te beslissen, de verhoren bijwonen. De gedachte vond in de Tweede Kamer algemeen bijval.

Het eenige wat men had moeten doen, wilde men werkelijk den ouden toestand doen herleven, liet men na: men had de gansche praktijk, die zich in strijd en naast de wet gevormd had moeten uitbannen. Dit deed men echter geenszins, veeleer sanctionneerde men haar. ${ }^{2}$ )

Het verhoor der getuigen door het college in plaats van door een rechter-commissaris bleef dientengevolge in de meeste gevallen een dwaasheid. De rechters oordeelden toch als regel op het proces-verbaal der getuigenverklaringen en niet onder den versehen indruk van het

I) H. R. 19 Nov. $1852 W .1470 ; 19$ Oct. 1866 W. 2846 en 10 Nov. 1876 W. 4050 .

2) Wel deed dit het antwerp 1865. Zie art. 56 en toelichting. Het is én der groote verdiensten van dit ontwerp. 
mondeling gehoorde. Gegeven deze vast ingeroeste praktijk was het dan ook een verbetering, dat in 1905 in de wet de mogelijkheid geopend werd dat het getuigenverhoor door een rechter-commissaris kon afgenomen worden; wie een getuigenverhoor voor een kamer eener drukké rechtbank heeft bijgewoond en de weinige belangstelling waarneemt, waarmede de bijzittende rechters het verhoor volgen, omdat zij toch warsehijnlijk niet of eerst veel later aan het vonnis zullen meewerken, zal dit onmiddelijk toegeven. Maar dit neemt niet weg, dat de wijziging in 1905 wederom is geweest een zonder protest zich neerleggen van den wetgever bij een stelsel, dat geen undere basis had dan de slenter der pralstijk. ${ }^{1}$ )

Toen de rechter ophield te ronnissen onder den versehen indruk van het afgenomen getuigenverhoor, kjeeg ook het proces-verbaal der getuigenverklaringen een beteekenis, die het oorspronkelijk in de rolprocedure niet had. Het werd het stuk, waarop gevonnisd werd.

De rechtbank te 's-Hertogenbosch mocht nog bij vonnis van 13 Februari 1867 W. 2929 volkomen terecht beslissen, dat het.opmaken ran een proces-verbaal alleen is voorgeschreven voor den reehter, die niet zelf de getuigen heeft gehoord en dat mitsdien onmiddellijk na het getuigenverhoor tot de pleidooien kan overgegan worden, zonder dat aan partijen den tijd behoefde gelaten te worden om het procesverbaal te lichten en in het geding te brengen, dit was reeds toen een stem, die inging tegen een rastgeroest gebruik. Elı gelijk op zoovele andere punten, sloot ook hicr de wetgever van 1896 zieh bij die praktijk aan door in alle zaken het opmaken van een proces-verbaal van het getuigenverhoor verplichtend te stellen.

Om dit proces-verbaal draait thans alles: de rechter verlangt, dat

1) Omtrent de wenschelijlkheid van het getuigenverhoor voor een rechter-conmissaris, vergelijko men in overeenkomstigen ain: EuJsselı, in Themis 1903, bl $613 \mathrm{vlg}$. en S. Gratras in W. 7917. Het tegenovergestelde standpant, passende voor een praktijk, die echter nict bestond, is nog verdedigd door den hoofdredacteur van het W. v. h. $R$. in $\mathrm{n}^{\text {? }} \mathbf{7 9 0 8 .}$

Overigons is do gesthiedenis van het procesrecht ook op dit punt één herhaling: Het verhoor van getuigen voor een rechter-commissaris was in Frankrijk gebruikelijk totdat verschillende ordonnantios daartegen voor sommige zaken reageerden (van 15 Februari 15.9, art. 23; van October 1585, eh 12, art. 5; en Januari 1560 , art. 57; van Mei 1579, art. 153); het Ilatst bij de ordonnantie van 1667 (tit. 17, art. 8).

Maar de praktijls is steeds den rechter-commissaris blijven handhaven "Il est rare", zegt Ronie?, "que daus aucune juridiction les témoins soient auis en l'audience". (Q)entions b1. 285) De Code sohreef weer het verhoor ter rechtzitting voor. De praktijk reageorde echter opnieuw daartegen. 
hem daarvan een afschrift wordt overgelegd; de eerste daad van hem, die een enquî̀te gehoudon heeft, is dan ook cen afschrift van het proces-rerbaal aan to vragen; eerst na ontvangst daarvan begint hij zijn conclusic ma enquête op te stellen.

Aldus liggen thans tussehen getuigenverhoor en vonnis in: aanvrage van een afsehrift van het proces-verbaal, lichting van dit afschrift, conclusies na enquête en pleidooi, dit alles terwijl de bedoeling der wet en de acnvaukelijke praktijk geen andere was, dan dat na het getuigenverhoor onmiddellijk of met korte tusschenruimte het pleidooi zou volgen, evenals dit thans nog in strafzaken het geval is.

\section{XII.}

Zeer merkwaardig is verder de wijze, wairop het uitstelvragen zich in de rolprocedure ontwikkeld heeft.

De Code de procédure civile schreef in art. 405 voor, dat, na verloop van den termijn van dagvaarding, de zaak ter audiëntie zonder eenige procesvorm of formaliteit zou gevonnisd worden. Het decreet van 30 Maart 1808 verklaarde in art, 66, dat slechts om buitengewone redenen de rechtbank een uitstel van bepaalde duur kon toestaan.

Dezelfde gedachte heeft bij den wetgever van 1838 voorgezeten. Bij het eerste ontwerp van 1837 word bepaald, dat de conclusies van partijen en het pleidooi op den dag, wartegen gedagvaard werd (de dienende dag) moesten gehouden worden.

Naar aanleiding van een opmerking van de vierde afdeeling werd echter deze wijziging aangebracht, dat voor het nemen van de conclusies een uitstel kon toegestann worden en ook voor de pleidooien een nadere dag kon bepaald worden ( $\mathrm{v}$. D. Hon ERT. op $\$ 138$ en $\$ 139$ ).

De bedoeling der wet was echter, dat het uitstel uitzondering, afhandelen der zaak op den dienenden dag regel zou zijn; verder wenschte de wet slechts een éénmalig uitstel geven.

Toen dan ook de tweede afdeeling der Tweede Kamer voorstelde, dat er tusschen den dag waartegen gedagvaard was en den dag van het pleidooi ten minste veertien en ten hoogste vier weken zouden verloopen welke lantste termijn door den rechter in het belang van partijen in bijzondere gevallen eenigszins kon verlengd worden, verzette zich de Regeering daartegen op dezen grond, dat door het voorstel den noodigen spoed in de behandeling geheel zou worden weggenomen en men in spoed vereischende zaken telkens tot de verkorting der termijnen het bref délai — zijn toevlucht zou moeten nemen ( 
De Regeering beschouwde dus de wettelijke regeling als een, waarbij gewaarborgd was, dat tusschen den dag, waartegen gedagvaard was en den dag van pleidooi als regel minder dan rier woken zouden verloopen!

Het herhaalde uitstel geven is in praktjik gekomen, als een onderlinge inschikkelijkheid der procureurs, waartegen de rechter, het gevaar voor de rechtspleging niet volledig beseffend, niet met de noodige kracht gereageerd heeft ${ }^{1}$. Welhaast werd het usance, dat men recht op een herhaald uitstel had, als niet bij de bewilliging van een vorig uitstel door de wederpartij verklaard was, dat hij het uitstel peremptoor verleende.

Maar toch was nog in 1876 de herinnering aan wat de wet eigenlijk gewild had, niet geheel verloren. Een partij verzette zich tegen herhaald uitstel en achtte dit in strijd met de wet. De praktijk was toen echter al te veel ingeburgerd, dan dat de rechter, bij het ontbreken van een uitdrukkelijken wetstekst, het uitstel weigeren dorst. Het Hof te Amsterdam verklaarde, dat wanneer er voldoende gronden aanwezig waren, het niet verboden was herhaalde uitstellen tot het nemen van conclusiën te verleenen. Men lette wel: er staat nog indien er voldoende gronden aanwezig zijn ${ }^{2}$ ).

De wetgever van 1896 is hier wederom opgetreden als sanctioneerend de misbruiken der praktijk. Artikel 143 bepaalt thans, dat de termijnen roor het nemen der conclusiën door den rechter bepaald worden in overeenstemming met hetgeen de partijen verlangen. Zijn derhalve partijen het amtrent het uitstel eens, dan moet de rechter zich daarbij neerleggen.

\section{XIII.}

'fegelijk met het in de sumniere procedure in zwang komen der conclusies van repliek en dupliek en het herhaald uitstel geven gingen

1) Zie DE Pinto II $\$ 126$ : Dadelijk pleidooi na de conclusies op dezelfde teregtzitting schijnt in de bedoeling der wet regel te zijn, pleidooi op eenen waderen regtsdag uitzondering...; de practijk heeft dit echter omgekeerd en de uitzondering tot regel, den regel tot nitzonrlering gemaakt."

Ook een inzender in $I T .280$ spreukt vam het misbruik dat van het vragen en verleenen van uitstel gemakkt wordt. Deze inzender zocht alreeds de fout bij de menschen en niet bij de wet.

2) Ook in Frankrijk heeft overigens de praktijk do summiere procedure zijn oorsproukelịk karikter doen verliezen. De eerste sporen daarvan vindt men reeds aangestipt bij Boncenne-Bourbeau, Théorie de la procédure civile VI, 83 (1847). 
ook de incidenteele conelusies meer belemmerend op den loop der procedure werken.

Aanvankelijk was het in de summiere procedure gebruik, dat incidenteele conclusies op den dag wartegen gedagvaard was, den dienenden dag, werden genomen.

Art. 141 Rv. schreef in aansluiting daarmede uitdrukkelijk voor, dat incidenteele vorderingen, tusschenkomst en voeging in summiere zaken ten dienenden dage ter audiëntie moesten genomen worden. En voor een wetgever, die zich de conclusiën genomen dacht op den dag, waartegen gedagvaard was, was dit hetzelfde als wat art. $288 \mathrm{Rv}$. bepaalde: nadat de conclusiën door partijen genomen waren, kon geen voeging en tusschenkomst meer plaats hebben ${ }^{1}$ ).

Op het laatste oogenblik was echter bij de totstandkoming van het wetboek bepaald, dat voor het nemen der conelusiën eenig uitstel kon . toegestaan worden. Nochtans werd art. 141 Rv. in verband daarmee niet gewijzigd, echter evenmin art. 288. Zou men nu art. $141 \mathrm{Rr}$. laten overwegen, of art. $288 \mathrm{Rv}$.? Een tijd die weinig voelde om de procedure te bekorten, koos natuurlijk het laatste. Op grond van art. $288 \mathrm{Rv}$. werd onder dienende rechtsdag in art. $141 \mathrm{Rv}$. verstaan iedere dag waarop de zaak ter audiëntie voor bet nemen van conclusiën diende en niet, zooals in de artt. 135, 137, 138, 139 en 142 Rv. de dag, wasrtegen gedagvaard was. Aldus besliste de H. R. reeds bij arrest van 24 Mei 1850 W. 1138 .

Deze beslissing op zich zelf was niet in strijd met een goede procesorde; zij werd dit echter wel, toen de herhaalde uitstelien voor de conclusies gebruikelijk werden en toen de conclusies van repliek en dupliek in zwang kwamen. De Hooge Raad erkende uitdrukkelijk bij arrest van 10 April $1884 W .5027$ dat ook op de dagen voor het nemen van een conclusie van repliek of dupliek bepaald, in summiere zaken nog een incidenteele conclusie mogelijk was. Nu kon men verschillende incidenteele conclusies na elknar nemen. Ieder incident vormde op zich zelf een tussehengeding, dat de hoofdzaak onderbrak. Een nieuwe factor, die de procedure oploste en in verschillende elkander opvolgende bedrij ven verdeelde, was daarmede geschapen.

De wetgever van 1896 heeft ook bij de incidenteele conclusies de praktijk gesanctionneerd. Wel bepaalt art. $247 \mathrm{Rv}$. nog: Incidenteele

1) Slechts ten aanzien van het hooren op vrangpunten en het opdragen van den beslissenden eed was bepald dat daartoe in iederen stand van het geding kon geconcludeerd worden (art. 1962 B. W. en art. 237 W. v. B. R.). 
vorderingen worden ten dienenden dage ter audientie gedaan, maar om ieder misverstand wat onder ten dienenden dage bedoeld is te vermijden, spreekt art. 286 bij de voeging en tusschenkomst van: nter terechtzitting ten dienenden dage vóór of op dien, waarop de laatste conclusie in het aanhangig rechtsgeding wordt genomen."

Ja, ondat deze toevoeging in art. $247 \mathrm{Rv}$. ontbreckt, kan men au zelfs a contrarie redeneerend, volhouden, dat andere incidenteele conclusies dan voeging of tusschenkomst ook nadat de zaak afgeconcludeerd is, zelfs na pleidooi en vonnis, zoolang er nog maar een dag is, waarop de zaak ter andientie dient, kunnen genomen worden. De praktijk heeft zich inderdaad van deze nitlegging meester gemaakt. Een poging, onlangs gedaan, om zich daurtegen te verzetten, vond bij den rechter geen steun (Hof 's Hage 29 April 1918, W, 10328). Wanneer na pleidooi een interlocutoor vonnis wordt gegeven, heropent dit de litiscontestatie, hetgeen vanzelf medebrengt, dat partijen wederom incidenteele conclusies kunnen nemen; aldus het Hof. Een heropening der litiscontestatie, wie, die nog iets van zijn Romeinsch recht afweet, staat bij dit argunient niet onthutst?

De incidenteele vorderingen sijn door de praktijk in den loop der jaren verder nog voorzien met attributen van kleine op zich zelf staande procesjes; men concludeerde met de noodige uitstellen in het incident, men fourneerde stukken voor een dag ter pleidooibepaling, men bepleitte het incident, alles, evenals in de hoofdzaak.

De wetgever van 1896 is ook hier wederom sanctionneerend opgetreden; de mogelijkheid van uitstel werd erkend en de verleening daarvan, ook bij. de incidenteele conclusies, aan het verlangen der partijen ondergeschikt gernaakt. Eveneens werd de bevoegdheid om het incident na het wisselen der conclusies te bepleiten, in de wet vastgelegd. (Zie art. 247, 2e lid B. W.)

\section{XIV.}

Ik ben hiermede aan het einde gekomen van de tak, die ik mij zelve gesteld had. Ik heb, naar ik hoop, duidelijk gemaakt, hoe het gekomen is, dat niettegenstaande twee rezenlijke verbeteringen in de wetgeving 1), de procedure van heden veel omslachtiger en slechter is dan die van honderd jaar geleden.

1) Want ook de wetgever van 1896 heeft niet uitsluitend de gevormde praktijk gesanctionneerd; op menig punt heeft hij verbetering gebracht. Ik wijs slechts op de artt. $1412 \mathrm{e}$ lid, en $3872 \mathrm{2e}$ lid. 
Men kan uit dit stuk geschiedenis deze les trekken, die men welhaast uit de geschiedenis van iodere procesorde putten lkan: een goede en snel functionneerende procedure is voor slechts een gering deel een zaak van wetgeving; hoofdzakelijk is het een angelegenheid van personen en persoonlijke eigenschappen.

Men roept thans bij ons luide om een nieuw procesrecht. Fn inderdaad dit is noodig. Maar noodig op dezelfde wijze als men een misdadiger, die zich beteren wil, voor alles in een nieuw milieu moet brengen, opdat de invloed van het verleden gebroken worde.

Men hoede zich nochtans voor de meening, dat ook zonder dat bij rechters en advocaten de ernstige wil is om cen snelle on deugdelijke procedure te bewerkstelligen en in stand te houden, een wettelijke regeling dit zou kmnnen verzekeren. Jraconische bepalingen, waarmede men een snellen procesloop heeft willen afdwingen, hebben steeds averechts gewerkt. Geen deel van het recht wordt meer ge- en vervormd door de praktijk dan het procesrecht.

Slechts door den ernstigen wil van hen, die in het proces een werkzame rol vervullen, kan een duurzame verbetering komen. De overtuiging moet eerst gewekt worden, dat onze procesorde gelijk ze zich thans in de praktijk voordoet, ernstige gebreken heeft, die de rechtspraak in discrediet brengen. En naast deze overtuiging kome dan de wil te staan, om datgene, wat gedurende korte of lange perioden in vroeger eeuven nu en dan bestaan heeft, wat thans wederom in de rechtspraak van vaste arbitragecommissies en administratieve rechters mogelijk blijkt, ook in de civiele rechtspraak te verwezenlijken: een snelle en doelmatige procedure.

\section{$X \nabla$.}

Wat thans nog volgt staat buiten het historisch overzicht dat ik gegeven heb, en hoort streng genomen in een historisch tijdschrift niet thuis. Toch kan ik de verleiding niet weerstaan, om aan te geven, hoe mijns inziens, de praktijk van heden zich stellende op den bodem van de thans geldende wet, vele fouten, die langzamerhand naar binnen geslopen zijn, wederom ongedaan kan maken.

Vóór alles moet wederom meer concentratie in de procedure gebracht worden. Het is een op geen enkel wettelijk voorsehrift steunend iets, dat men eerst de rechtskwesties uitvecht en beslist, om daarna een geheel op zich zelf ataand bedrijf, het getuigenverhoor, to beginnen. Men heeft wel opgemerkt, waarom een getuigenverhoor te doen 
voorafgaan, als daarna bij de berechting der rechtsvragen kan blijken, dat het geheel nutteloos geweest is, omdat ook bij het bewezen zijn der feiten den eischer zijn eisch toch niet volgen kan? Maar daartegenover kan men met evenveel recht omgekeerd redeneeren: waarom de zaak door lange debatten en beschouwingen omtrent rechtskwesties op te houden, als daarna bij het getuigenverhoor zonneklaar zal blijken, dat de eischer geen schijn van biswjs voor de door hem gestelde feiten kan bijbrengen? ${ }^{1}$ )

Op deze wijze kan men niet tot een voorkeur komen noch voor het vóór laten gaan van een onderzoek der feiten, noeh voor de voorbehandeling der rechtsuragen. Wat echter de eerste handelwijze in de meeste gevallen verre verkieselijk boven de andere maakt, is, dat wanneer men het getuigenverhoor vooraf laat gøan, men één geconcentreerde behandeling van rechts- en feitelijke vragen in het daarop volgend pleidooi en vonnis verkrijgt on de beide rubrieken van vragen door den rechter sneller te zamen berecht worden, dan wanneer zij successievelijk behandeld worden. Bovendien is het voor den rechter ook voor de beoordeeling van de rechtsvragen gewoonlijk van het grootste belang, dat hij zich door het getuigenverhoor een juist beeld omtrent de feitelijke toedracht der zaak heeft kunnen vormen. Ook het feit, dat de rechter, die het eindvonnis velt, een geheel andere opvatting omtrent de rechtsvragen kan hebben dan de rechter, die in het interlocutoor deze reeds beslist heeft, leidt tot ongewenschte resultaten. Want of de eindrechter geeft alsdan een uitspraak, die hij onrecht acht of hij verbetert de foutieve rechtsoverwegingen, doch voert alsdan een nieuwe instantie in, die onvermijdelijk er toe moet leiden, dat ook partijen in haar conclusiën en uiteenzettingen de zaak als in een nicuwe instantie gaan behandelen 2). Ten slotte - en dit is niet het minst belangrijke - mag men ook weleens bedenken, dat hoe later men het getuigenverhoor in de procedure plaatst, des te meer zijn de getuigen vergeten, des te grooter is de kans, dat zij door partijen beïnvloed rijn. Buiten de civiele rechtspraak in die voor straf-, ongevallenen belastingzaken, bij tiendwetcommissies en andere colleges met admi-

1) De allerslechtste wijze van procedeeren is natuurijik, die, waarbij de rechter eerst de rechtskwestie ter volle laat bepleiten. en dan bij interlocutoor deze niet oplost, maar in de hoop, dat de zaak wel op feitelijke gronden zal stranden, getuigenbewijs oplegt.

2) Fen typisch staaltjo, hoe moeielijk, zoo niet ondoenlijk het is, voor den rechter van het eindvonnis zich bij een $z . j$. onjuist interlocutoor neer te leggen, levert b.v. Rb. Utrecht 17 Januari $1912 W .9425$. 
nistratieve rechtspraak aarzelt men dan ook niet om getuigen te hooren cn fcitclijk materiaal te verzamelen, vóórdat de rechtsviagen beslist zijn.

Een vóórbehandeling der rechtsvragen is wellieht in cen kleine, nog weinig gecompliceerde maatschappij, als Rome ten tijde der republiek was, op haar plaats, evenzoo in een procesrecht, waarbij men bewijsmiddelen als tweegevecht en ordelen kent, voor ous tegen woordig rechtswezen deugt het stelsel niet. Er kunnen natuurlijk geschillen zijn, waarin het den rechter met éen oogopslag duidelijk is, dat de gestelde feiten niet tot het gevraagde gevolg kunnen leiden of dat het geschil slechts op ondergeschikte punten van feitelijken aard is; alsdan kan een behandeling der rechtsvragen vóór gaan. De rechtspraak van den Zntfenschen rechter, die eerst vaststelde of een door den eiseher gestelde impotentie door de overgelegde brieven bewezen was, om daarna tot de opmerking te komen, dat impotentie geen eisch tot nietigverklaring van het huwelijk rechtvaardigde, wensch ilk niet te doen herleven ${ }^{1}$ ). Maar wel wensch ik hetzelfde stelsel als dat in 1883 in Engeland een eind heeft gemaakt aan de voorbehandeling der rechtsvragen (demurrers) en daar thans met succes werkt, dat nl. na het nemen van de conclusies cen rechter - in Engeland the master of the rolls — zich door een summier onderzoek overtuigt en daarna beslist of bepleiting der rechtskwestie dan wel het getuigenverhoor vóór moet gaan ${ }^{2}$ ). Ook de commissies van de Ned. Juristenvereeniging en van den Vrijzinnig-Democratischen bond hebben in hun ontwerpen dit beginsel overgenomen ${ }^{3}$ ).

Dit stelsel is reeds thans bij ons te verwezenlijken. Wat meer zegt, het is datgene, wat het meest in overeenstemming met de wet is. Men bedenke daartoe slechts, dat wanneer thans in een conclusie in de hoofdzaak, voor zooveel noodig getuigenbewijs aangeboden wordt, dit nog steeds in ons recht een incidenteele conclusie en wel - gelijk ze genoemd werd, toen ze zich begon in te burgeren -- cen subordinate incidenteele conclusie is.

Waar nu tegelijk èn in de hoofdzaak èn in een incident geconcludeerd is, vindt art. $249 \mathrm{Rr}$. toepassing: incidenteele vorderingen kunnen vóraf worden nitgewezen, doch behoeven dit niet. En door het

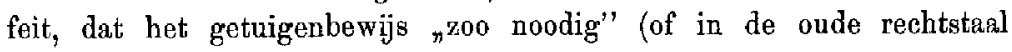

1) Rb. Zutfen 24 October $1839 W, 76$.

2) Zie daaromtrent J.Paulus, Het burgerlige geding voor de Kings Beneh division. Diss, Leiden 1905, bl. 95 vig.

3) Vooral duidelijk is bet antwerp van den Vrijz. Dem. Boud: artt. 61 ou 62 met toelichting; minder duidelijk het ontwerp van de Nederlandsche Juristen vereeniging art, 128 en vlg. 
nsubordinaat") aangeboden wordt, kan de rechter niet gedwongen worden, een andere volgorde in acht te nemen, dan die de wet hem aanwijst. Meent hij ap grond van art. $59,3^{\circ} \mathrm{RF}$. en in het belang der zaak, dat eerst de feitelijke vragen beslist moeten zijn, voordat de rechtsvragen mogen uitgewezen worden, dan kan een partij daarin geen verandering brengen door zijn bewering: ik hied alleen getnigenbewijs aan voor het geval, dat mijn juridieke beschouwingen onjuist zijn. Het getuigenbewijs moet plaats hebben op het oogenblik, dat volgens het stelsel der wet daarvoor aangewezen is, en niet op dat, waarop de partij het wenscht. Op geheel gelijke wijze houdt de Hooge Raad zich bij de behandeling van cassatiemiddelon steeds aan de volgorde, die hij de juiste acht, zonder zich aan de door den eischer. gekozene te binden.

De loop eener procedure, wantin getuigeubewijs angeboden wordt terwijl daarnaast rechtsvragen zich voordoen, kan dientengevolg̈e als volgt zijn: worden de stukken gefourneerd voor vonnis of pleidooi, dan onderzoekt de rechtbank summierlijk wat vóór dient te gaan, het. incident, dat is het verzoek tot getrigenverhoor, of de hoofdzaak.

Meent zij - en ik zou dit tot. regel gemaakt willen zien - dat het getuigenverhoor voor moet gaan -, dan wordt alleen gelegenheid gegeven het incident te bepleiten. Het pleidooi en het vonnis in dit incident behoeven alsdan slechts zeer kort op te houden. De rechtsvragen van de hoofdzaak tcr zijde gelaten, zal er meestal niet veel te bepleiten over zijn; hoogstens of krachtens de artt. 1933 en vlg. B. W. getuigenbewijs toelaatbaar is. Het ter zake dienende en afdoende worde, evenals dit vroeger het geval was, slechts opgerat als recht gevend tot een summier onderzock, maar viet tot een ampele bespreking van rechtsvragen uit de hoofdzaak; feitelijk heeft dan de rechtbank door het indicent alleen te doen bepleiten, rceds dat summiere onderzoek verricht. Op deze wijze opgevat, zal een pleidooi bij het incident tot getuigenverhoor, evenals vóór 100 jạar, wederom hooge uitzondering worden en wanneer het plaats vindt, zeer kort en beknopt gehouden kunnen worden. Persoonlijk ingriijpen van den president kan nutteloos lang uitweiden bij een incident voorkomen. Het vonnis, waarbij het getuigenverhoor wordt toegelaten, kan wanneer het wederom zijn oude kortheid terug krijgt, zeer snel volgen. Het behoeft na een resumé van de beweringen der partijen, niets anders te bevatten, dan: overwegende, dat het bewijs door getuigen in deze niet is uitgesloten en tot beslissing der zaak kan leiden, alvorens ten principale recht te doen, enz.

Getuigenverhoor en tegenverhoor worde door den rechter steeds onmiddellijk na elkaar gchouden. Nocht de tegenpartij van hen, die het 
bewijs levert, naar aanleiding der afgelegde verklaringen, nog getuigen willen hooren, aan welke hij aanvankelijk niet dacht, het staat aan den rechter of hij uit dien hoofde voortzetting van het getuigenverhoor op een naderen dag wenseheijk acht (art. $104 \mathrm{Rv}$.).

Bij arrest van des Hoogen Raad van 17 Maart $1876 \mathrm{~W} .3970$ is wel uitgemaakt, dat de rechter de beroegdheid heeft om het tegenverhoor op een lateren dag te bepalen, maar de Hooge Raad heeft nog nimmer het omgekeerde beslist, dat de rechter de bevoegdheid zou missen om het tegenverhoor onmiddellijk na het verhoor te plaatsen. De practici hebben daartegen echter altijd dezelfde bezwaren. Het is ateeds een herhaling van hetgeen door G. M. vaN DER LINDEN in Themis V, bl. 31, dienaangaande opgemerkt is. De wederpartij weet van tevoren niet wat de getuigen in de enquête zullen verklaren; eerst pa dat gehoord te hebhen, weet hij waartegen hij tégenbewijs moet leveren en wolke getuigen hij daarvoor moet doen hooren. Dat een dergelijk argument in een periode van verslapten ijver ingang kon viuden, is begrijpelijk, maar desniettemin is zijn innerlijke waarde gering. De wederpartij. weet door het interlocutoor, welke feiten het voorwerp van het bewijs uitmaken. Kent hij personen, die het tegendeel kunnen getnigen, hij roepe die op. Oordeelt hij, dat de getuigen van de andere partij niets bewezen hebben, daa kan hij van het hooren van zijn getuigen af zien ${ }^{1}$ ). Verklaren de getuigen van de andere partij geheel onvoorziene feiten die vermoedens kunnen opleveren en dreigt aldus het gevaar van verrassing, dan is er toch nog altijd de rechtel, die voortzetting van het getuigenverhoor op een naderen dag bevelen kan.

Het houden van enquête en contra-enquête onmiddellijk na elkatr heeft behalve het voordeel, dat het de behandeling der zaak concentreert, ook nog dit andere, dat het een prikkel te meer voor beide partijen is, om zelve bij het getuigenverhoor aanwezig te zijn. 'Trouwens een recbter, die de burgerlijke procedure, evenals een strafzaak, in één zitting concentreeren wil, en zich zoo volledig mogelijk wil laten voorlichten, roepe. in iedere zak van eenig belang tegen dezelfde zitting, als waarop het getuigenverhoor gehouden zal worden, krachtens art.

1) Er zullen wel personen zịjn dic mecnen, dat men den bewijslast omkcert, wanneer de wederpartij, ook voordat er iets hewezén is, haar getuigen dient op te roepen. Marar dan moet men ook consequent zijn, dan moet men zeggen tegenbewijs veronderstelt een reeds guleverd bewịs. De wederpartij, aan wie van rechtswege het tegenbewijs tockomt, behoeft dit eerst te leveren, nadat bij vonnis beslist is, dat, behoudens tegenbewijs, de andere partij haar feiten bewezen heeft. 
49 Rv. de partijen op. Hij kan dan de getuigenverklaringen met de opgaven van partijen aavvullen en controleeren.

Onmiddellijk na afloop van het getuigenverhoor worden aan partijen of hun raadslieden gelegenheid gegeven tot het houden van het pleidooi. Geen lichting van het proces-verbaal door partijen, geen conclusies na enquête, al te maal door de wet niet vereischt, houden de zaak op; het vonuis zij gewezen onder den nog verschen indruk van de afgelegde verklaringen. Bij deze wijze van procedeeren blijve natuurlij]k uitgesloten, dat de rechtbank gebruik maakt van de haar gegeven bevoegdheid om op eenparig verzoek van partijen een getuigenverhoor voor een rechter-commissaris te doen houden.

Ziedaar wat reeds krachtens onze tegenwoordige wet mogelijk is. Is er een rechtbank te vinden, die den moed hoeft met de sleur der praktijk te breken? Of gaat het met de praktijk als met rivieren? Zij stroomen wel van hoog naar laag, maar nimmer terug van laag naar hoog. 